\title{
Malformed agnostids from the Middle Cambrian Jince Formation of the Príbram-Jince Basin, Czech Republic
}

\author{
OLDŘICH FATKA, MICHAL SZABAD \& PETR BUDIL
}

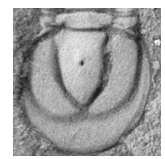

\begin{abstract}
Two agnostids from Cambrian of the Barrandian area bear different types of skeletal malformations. The tiny pathological exoskeleton of Hypagnostus parvifrons (Linnarsson, 1869) has asymmetrically developed pygidial axis, while the posterior pygidial rim in the larger Phalagnostus prantli Šnajdr, 1957 has an irregular outline. • Key words: agnostids, Middle Cambrian, Jince Formation, Př́bram-Jince Basin, Barrandian area, Czech Republic.
\end{abstract}

\begin{abstract}
FATKA, O., SzABAD, M. \& BUdiL, P. 2009. Malformed agnostids from the Middle Cambrian Jince Formation of the Př́ibram-Jince Basin, Czech Republic. Bulletin of Geosciences 84(1), 121-126 (2 figures). Czech Geological Survey, Prague. ISSN 1214-1119. Manuscript received November 11, 2008; accepted in revised form January 9, 2009; published online January 23, 2009; issued March 31, 2009.

Oldřich Fatka, Department of Geology and Palaeontology, Faculty of Science, Charles University, Albertov 6, Praha 2, CZ -128 43, Czech Republic; fatka@ natur.cuni.cz•Michal Szabad, Obránců míru 75, 26102 Př́bram VII, Czech Republic•Petr Budil, Czech Geological Survey, Klárov 3, Praha 1, CZ-11821, Czech Republic; petr.budil@ geology.cz.
\end{abstract}

\begin{abstract}
Numerous examples of exoskeletal abnormalities have been described in various polymerid trilobites (e.g., Owen 1985, Babcock 1993, Whittington 1997), including paradoxidid trilobites from the Cambrian Př́bram-Jince Basin of the Barrandian area (Šnajdr 1978). However, anomalous agnostid skeletons are very rare; there are only four Cambrian and one Ordovician malformed agnostid specimens recorded.
\end{abstract}

Babcock $(1993,2003$, 2007) documented and briefly described scars on the posterolateral pygidial margin in two isolated pygidia of Peronopsis interstricta White, 1874, both collected from the Middle Cambrian Marjum Formation (House Range, Utah, U.S.A.). These scars were interpreted as healed injuries of uncertain origin by Babcock (1993, 2003, 2007). Also, Buchholz (2000) interpreted one pathologic pygidium of the "Upper" Cambrian Agnostus procerus Buchholz, 1999 as result of a failed durophagous predation which he considered happened shortly after exuviation.

Another type of healed injury is recorded from Cambrian and Ordovician agnostids. Babcock (1993, 2003, 2007) figured dorsal and ventral views of a cephalon of Arthrorhachis elspethi Raymond, 1925 from the Middle Ordovician Edinburgh Limestone of Virginia, U.S.A. with a small boring along its right posterior pygidial axis. A similar, anteromedially inclined pit in the right posterolateral corner of the cephalic axis in a specimen of Ptychagnostus atavus (Tullberg, 1880) from the Middle Cambrian Huaqiao Formation in northwestern Hunan, China was discussed by Babcock and Peng (2001). Öpik (1967) described and figured one pathological pygidium of Glyptagnostus stolidotus Öpik, 1961 with hypertrophic development of the left side of the pygidium.

Partly broken and slightly scattered pygidial fragments of two complete specimens of Ptychagnostus stenorrhachis (Grönwall, 1902) and Ptychagnostus (Goniagnostus) sp. recorded by Jago (1974) from the Middle Cambrian Que River Beds of Tasmania were interpreted as the result of the activities of an unknown benthic scavenger.

This paper describes two new articulated agnostid specimens with malformed pygidia collected from different stratigraphical levels of the Jince Formation (Drumian, Př́bram-Jince Basin).

\section{Agnostids in the Jince Formation}

Agnostids have been known for more than 160 years from the Jince Formation of the Přibram-Jince Basin (Beyrich 1845, Barrande 1846). Since these pioneer works, several thousand intact agnostid exoskeletons and/or disarticulated parts of the eleven valid species have been collected at several tens of outcrops (Šnajdr 1958, Fatka et al. 2004, Fatka 2006). Such extensive material has allowed the recognition of three major agnostid assemblages: 1. Peronopsis-Phalagnostus Assemblage; 2. Phalacroma-Condylopyge Assemblage and 3. Onymagnostus-Hypagnostus Assemblage (Fatka et al. 2007). Stratigraphical and spatial 

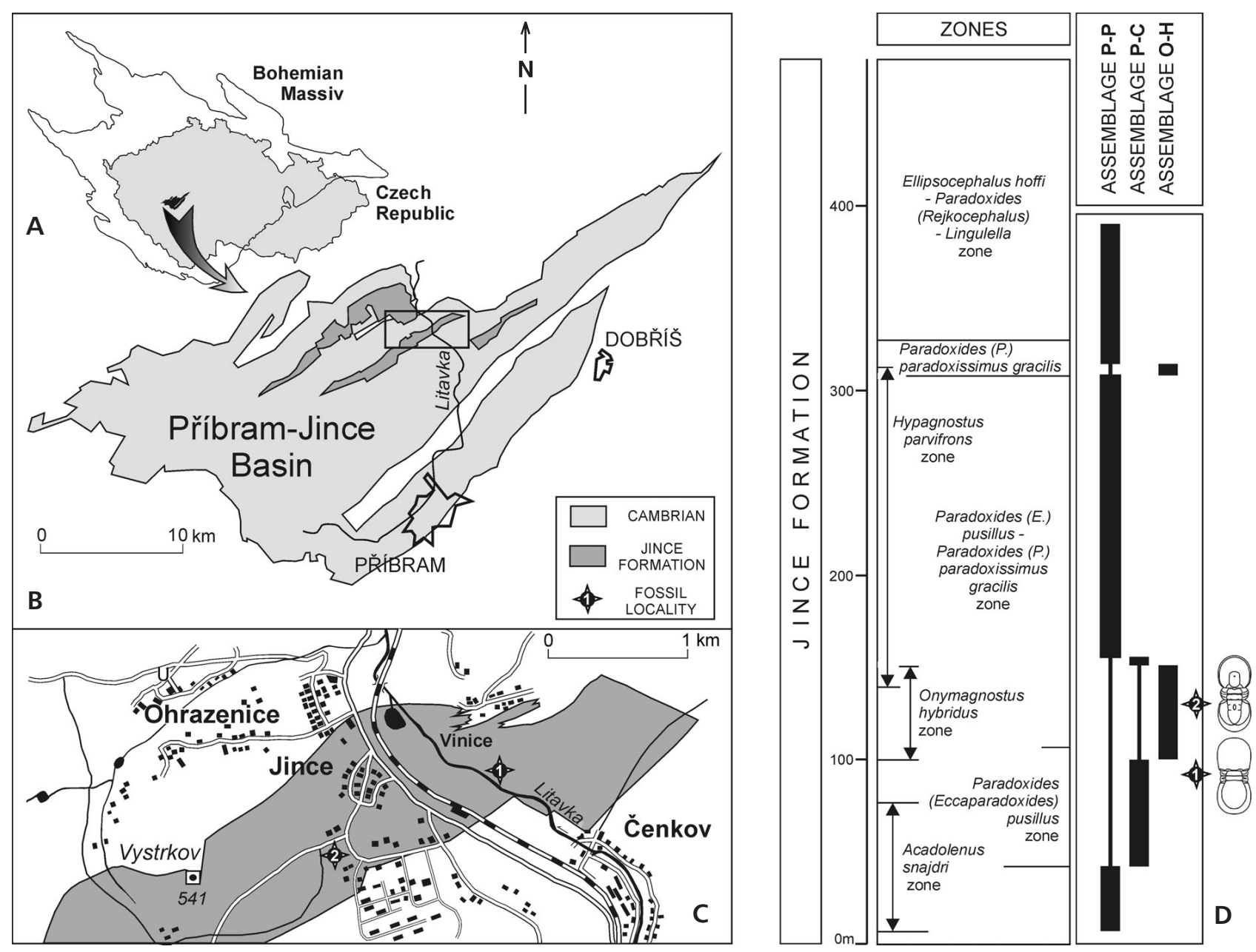

Figure 1. A - map of the Bohemian Massif showing the Czech Republic and the Příbram-Jince Basin. • B - sketch map of the Příbram-Jince Basin. - $\mathrm{C}$ - map of the Jince area showing location of outcrops at which the described materials have been found: (1) Vinice Hill locality near Jince, 2 Obalovna locality at Vystrkov Hill. Geology modified after Havlíček (1971). D - biostratigraphy of Jince Formation in the Příbram-Jince Basin with marked levels at which the malformed specimens of Phalagnostus prantli Šnajdr, 1957 and Hypagnostus parvifrons (Linnarsson, 1869) were collected. Also shown are the vertical distribution of agnostid assemblages $(\mathrm{P}-\mathrm{P}=$ Peronopsis-Phalagnostus; $\mathrm{P}-\mathrm{C}=$ Phalacroma-Condylopyge; $\mathrm{O}-\mathrm{H}=$ Onymagnostus-Hypagnostus). Modified after Fatka et al. (2004, 2007) and Fatka \& Szabad (in press).

distribution of these three assemblages reflect transgressive-regressive pulses during sedimentation of the Jince Formation and agree with the Cambrian biofacies model established by Bordonaro et al. (2008).

All the assemblages and the majority of agnostid species show an apparent relation to palaeobathymetrical and sedimentological gradients.

Recently two anomalous agnostid specimens have been collected at two different outcrops of the Jince Formation in the Litavka river Valley (Fig. 1). The first of the malformed specimens, an articulated exoskeleton of Phalagnostus prantli Šnajdr, 1957 was collected from higher levels of the Paradoxides (Eccaparadoxides) pusillus Biozone on the slopes of Vinice Hill near Jince (Fig. 1C, D). The second example is represented by an internal mould of a small articulated specimen of Hypagnostus parvifrons (Linnarsson, 1869) and comes from the stratigraphically higher Onymagnostus hybridus Biozone at the Obalovna locality at the Vystrkov Hill (Fig. 1C, D).

\section{Phalagnostus prantli Šnajdr, 1957}

Figure 2A, B

Description. - Complete exoskeleton with slightly displaced and rotated cephalon; pygidium and both thoracic segments associated, preserved as internal and external moulds in mudstone. Both moulds show atypically developed posteral pygidial margin as well as flattened pygidial furrow in its right postero-lateral sector (Fig. 2A). The pygidial margin bears five (?six) irregular bite (?) marks of different dimensions and shape. Three of them are interconnected (arrows a, b, c in Fig. 2B), two other a little smaller 'bites' are seen on the right postero-lateral part of 


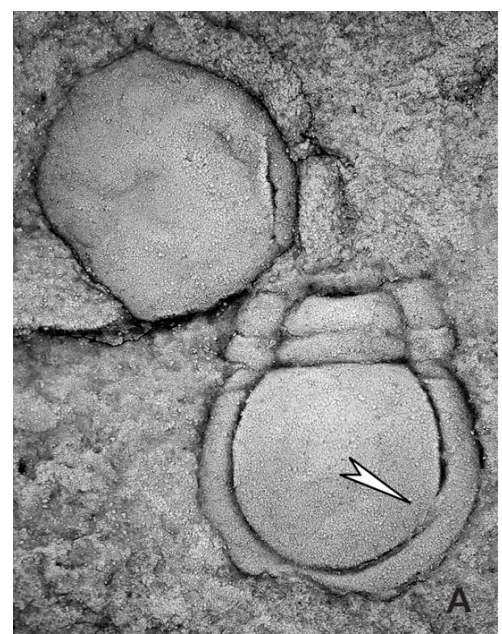

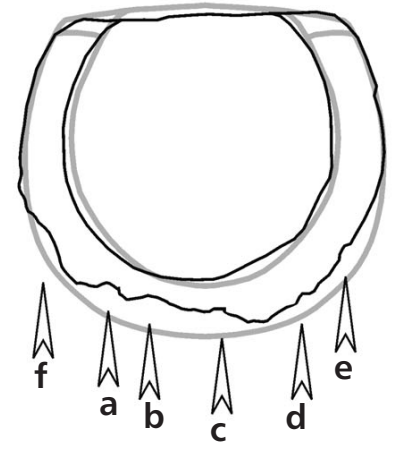

B
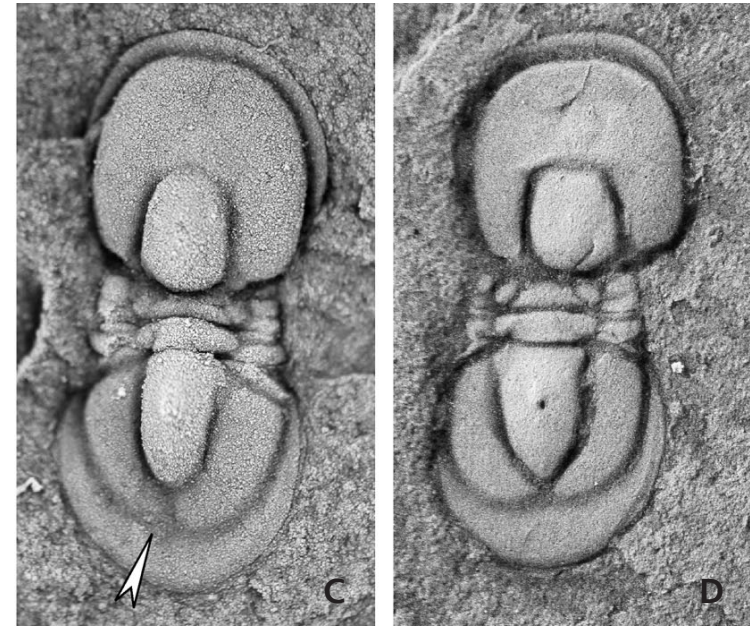

Figure 2. A - Phalagnostus prantli Šnajdr, 1957; internal mould with repaired injury on the posterior pygidial margin. CGS VL 176 . $・$ B - schematic drawing of the same pygidium (thin black line) with the six possible bites (arrows a-f) compared with normal pygidial morphology (grey line). - C - Hypagnostus parvifrons (Linnarsson, 1869); internal mould of pygidium with asymmetrically developed axial region. CGS SZ 227. - D - Hypagnostus parvifrons (Linnarsson, 1869); internal mould. CGS SZ 228. All specimens are stored in the Czech Geological Survey, Prague.

the pygidial margin (arrows d and e in Fig. 2B). The larger of the 'bites' is on the left postero-lateral sector of the pygidial margin (arrow $\mathrm{f}$ in Fig. 2B). Also, the right postero-lateral pygidial furrow is shallower and interrupted (arrow in Fig. 2A). All these morphological changes can be explained as resulting from a failed predatory attack.

Associated fauna. - At this outcrop the fossil association includes the common agnostids Phalagnostus prantli Šnajdr, 1957, Peronopsis integra (Beyrich 1845), Phalacroma bibullatum (Barrande, 1846), associated with complete specimens as well as disarticulated exoskeletal parts of the polymerid trilobites, e.g., Paradoxides (Eccaparadoxides) pusillus (Barrande, 1846), Paradoxides (Acadoparadoxides) sacheri (Barrande, 1852), Paradoxides (Hydrocephalus) minor (Boeck 1827), Conocoryphe spp., rare linguliformean and acrotretacean brachiopods, molluscs, edrioasteroid, eocrinoid and ctenocystid echinoderms and simple trace fossils (see Fatka et al. 2004). At this stratigraphical interval, agnostids of the shallow-water Peronopsis-Phalagnostus Assemblage occur together with taxa of the relatively deeper-water Phalacroma-Condylopyge Assemblage (Fig. 1D).

\section{Hypagnostus parvifrons (Linnarsson, 1869)}

Figure 2C, D

Description. - Internal and external moulds of the tiny intact specimen show assymetrically developed left posterolateral margin of the pygidial axis and the left lateral pleural lobe. This results in the pygidium showing an apparent assymetry when compared with normal specimens (cf. Fig. 2C, D).
Morphological changes on this pygidium recall the pathological specimen of Glyptagnostus stolidotus Öpik, 1961 in which the left side of the pygidium is also hypertrophic (see Öpik, 1967, p. 168, pl. 67, fig. 2).

Associated fauna. - At this stratigraphical level the fossil association is dominated by commonly articulated agnostids, Doryagnostus vinicensis (Šnajdr, 1957), Hypagnostus parvifrons (Linnarsson, 1869), Onymagnostus hybridus (Brogger, 1878), Peronopsis integra (Beyrich, 1845), Phalacroma bibullatum (Barrande, 1846), Phalagnostus prantli Šnajdr, 1957 and Tomagnostus perrugatus (Grönwall, 1902) associated with the common polymerid trilobite Paradoxides (Hydrocephalus) minor minor (Boeck, 1827) and the rare Luhops expectans (Barrande, 1852), as well as rare representatives of the bivalved arthropod $T u$ zoia Walcott, 1912 (see Fatka et al. 2004).

\section{Agnostid palaeoecology}

Mode of life of agnostids has been repeatedly discussed. Lochman-Balk \& Wilson (1958), Öpik (1961), Robison (1972, 1975) and Jago (1973) provided arguments for their planktic life habit. However, a benthic life habit was first proposed by Jaekel (1909), it has been considered also by Robison (1972) and Müller \& Walossek (1987) for several species of Peronopsis and for Agnostus pisiformis. More recently Babcock (1994), Nielsen (1997) and Chatterton et al. (2003) put forward various arguments for a benthic mode of life for agnostids. Also, Elicki \& Pillola (2004) classified the genera Condylopyge and Peronopsis as benthic detritus suspension- or deposit-feeders. Clusters of complete specimens of several Ordovician agnostid 
species were used as an argument for an epifaunal life habit by Pek (1977), Přibyl \& Vaněk (1976), Havlíček et al. (1993) and Slavíčková \& Kraft (2001). Öpik (1979) supported a microfiltration mode of life for agnostids on drifting algae, while Lochman-Balk (1940) supprted an infaunal mode of life. Bergström (1973) considered that agnostids were ectoparasites. In several detailed analyses by Clarkson et al. (1998), Eklöf et al. (1999), Turvey \& Zhou (2004) and Bruton \& Nakrem (2005) the agnostid life habit was left open. Recently Lin \& Yuan (2008) interpreted the eodiscid trilobite genus Pagetia as having benthic mode of life.

Lochman-Balk \& Wilson (1958, p. 322) wrote that "The Agnostidae also are esentially adapted to the extracratonic biofacies. Only the ubiquitous Peronopsis is common in cratonic sites, but more genera appear in the intermediate realm." Later, Robison (1975) elaborated a model of inferred depth stratification of agnostids. He supposed that the species Peronopsis fallax (Linnarsson, 1869) (= Peronopsis acadica Hartt (in Dawson, 1868) after Robison 1995) preferred to live in shallower water compared to some other agnostoids [e.g., Peronopsis interstricta (White, 1874) or species of the genus Ptychagnostus Jaekel, 1909].

\section{Discussion}

Documentation of ancient predation is difficult. However, in rare cases, direct evidence of predator attack is observable in the skeletons of prey organisms (see Vermeij 1987).

The host sediment of the studied agnostids; the fine greywackes and mudstones of the Jince Formation contain well-preserved, often articulated specimens of agnostids and polymerid trilobites ( $c f$. Fatka \& Szabad in press). The high proportion of articulated specimens suggests minimal transportation of the assemblage and rules out a mechanical (non-biological) origin as the cause of the damage to Phalagnostus. By analogy with repaired skeletal injuries in Cambrian and other trilobites, the marginal scars in Phalagnostus prantli are interpreted here as a repaired sublethal injury following failed predation.

Phalagnostus prantli may have been the prey of contemporaneous paradoxidid trilobites, whose functional morphology suggests a predatory lifestyle (Fortey \& Owens 1999, Babcock 2003). The other potential predator is the arthropod Tuzoia sp. which occurs only rarely in the given stratigraphical level of the Jince Formation.

The apparently assymetrical left posterolateral margin of the pygidial axis and the left lateral pleural lobe developed in both external and internal mould of Hypagnostus parvifrons is interpreted here as a possible teratology s. s., e.g., caused probably due to genetical malformation.

\section{Conclusion}

Within several thousand agnostids collected from the Jince Formation, only one exoskeleton shows a healed injury developed on the posterior pygidial margin, most probably representing sublethal predation. This low frequency of repaired injuries in the Cambrian Jince agnostids could reflect the inefficiency of Palaeozoic predators in breaking minute but robust $\mathrm{CaCO}_{3}$ exoskeletons, as supposed by Vermeij (1987).

The producer of the injury is unknown. It is likely that the potential predators known from the Jince Formation (paradoxidid trilobites with only weakly mineralized gnathobases and/or specimens of the genus Tuzoia) were most probably not able to crush the robust, minute and sphaeroidal but heavily mineralized agnostid exoskeleton.

The repaired injury is suggested to have been caused by an attack during the "paper shell" stage, i.e. soon after exuviation of the agnostid.

\section{Acknowledgements}

J. Valíček (Most) provided the specimen of Phalagnostus prantli for our study. S. Schultka (Museum für Naturkunde, Berlin, Germany) kindly sent us a copy of a very needed reference. We would like to express our sincere thanks to R. Gozalo (University of Valencia, Spain) and an anonymous reviewer for useful suggestions who substantially improved the paper. This study was supported by grants from the Ministry of Education (Project No. MSM0021620855) and the Czech Science Foundation through the Project No. 205/06/0395.

\section{References}

BABCOCK, L.E. 1993. Trilobite malformations and the fossil record of behavioral asymmetry. Journal of Paleontology 67(2), 217-229.

BABCOCK, L.E. 1994. Systematics and phylogenetics of polymeroid trilobites from the Henson Gletscher and Kap Stanton formations (Middle Cambrian), North Greenland. Bulletin Grønlands geologiske Undersøgelse 169, 79-127.

BABCOCK, L.E. 2003. Trilobites in Paleozoic predator-prey systems, and their role in reorganization of Early Paleozoic ecosystems, 55-92. In KeLLEY, P.H., KOWALEWSKI, M. \& HANSEN, T.A. (eds) Predator - prey interactions in the fossil record. xvi +464 pp. Kluwer Academic Publisher, New York, Boston, Dordrecht, London, Moscow.

BABCOCK, L.E. 2007. Role of malformations in elucidating trilobite paleobiology: a historical synthesis. In MiKULIC, D.G., LANDING, E. \& KLUESSENDORF, J. (eds) Fabulous fossils 300 years of worldwide reserch on trilobites. New York State Museum Bulletin 507, 2-19. 
BABCOCK, L.E. \& PENG, S.C. 2001. Malformed agnostoid trilobite from the Middle Cambrian of northwestern Hunan, China. In PENG, S-C., BABCOCK, L.E. \& ZHU, M-Y. (eds) Cambrian System of South China. Palaeoworld 13, 250-251.

BARRANDE, J. 1846. Notice préliminaire sur le système silurien et les trilobites de Bohême. 97 pp. Leipzig.

BARRANDE, J. 1852. Systême silurien du centre de la Bohême. Vol. I. Prague.

BERGSTRÖM, J. 1973. Organisation, life and systematics of trilobites. Fossils and Strata 2, 1-69.

BEYRICH, E. 1845. Über einige böhmische Trilobiten. 47 pp. G. Reimer, Berlin.

BoECK, C.P.B. 1827. Notiser til Laeren om Trilobiterne. Magazin for Naturvidenskaberen 1.

BORDONARO, O.L., BANCHIG, A.L., PRATT, B.R. \& RAVIOLO, M.M. 2008. Trilobite-based biostratigraphic model (biofacies and biozonation) for the Middle Cambrian carbonate platform of the Argentine Precordillera. Geologica Acta 6(2), 115-129.

BRøGGER, W.C. 1878. Om Paradoxidesskifrene ved Krekling. Nyt Magazin for Naturvidenskaberne 24, 18-88.

BRUTON, D.L. \& NAKREM, H.A. 2005. Enrolment in a Middle Ordovician agnostoid trilobite. Acta Palaeontologica Polonica 50(3), 441-448.

BuCHHOLZ, A. 1999. Agnostida (Trilobita) aus oberkambrischen Geschieben Mecklenburg/Vorpommenrs (Norddeutschland). Greifswalder Geowissenschaftliche Beiträge 6 (E. HerrigFestschrift).

BuCHHOLZ, A. 2000. Die Trilobitenfauna der oberkambrischen Stufen 1-3 in Geschieben aus Vorpommern und Mecklenburg (Norddeutschland). Archiv für Geschiebekunde 2, 697-776.

Chatterton, B.D.E., Collins, D.H. \& Ludvigsen, R. 2003. Cryptic behaviour in trilobites: Cambrian and Silurian examples from Canada, and other related occurrences. Special Papers in Palaeontology 70, 157-173.

Clarkson, E.N.K., AhlberG, P. \& TAYlor, C.M. 1998. Faunal dynamics and microevolutionary investigations in the Upper Cambrian Olenus zone at Andrarum, Skåne, Sweden. GFF 120, 257-267.

DAWSON, J.W. 1868. Acadian geology. The geological structure, organic remains, and mineral resources of Nova Scotia, New Brunswick, and Prince Edward Island. Second edition. 694 pp. MacMillan \& Co., London.

EKLÖF, J., RYDELl, J., FRÖJMARK, J., JohANSSON, M. \& SEILACHER, A. 1999. Orientation of agnostid shields in Alum Shale (Upper Cambrian): Implications for the depositional environment. GFF 121, 301-306.

Elicki, O. \& PILlOLA, G.L. 2004. Cambrian microfauna and palaeoecology of the Campo Pisano Formation at Gutturu Pala (Iglesiente, SW Sardinia, Italy). Bolletino della Società Paleontologica Italiana 43(3), 383-401.

FATKA, O. 2006. Biostratigraphy of the Jince Formation (Middle Cambrian) in the Příbram-Jince Basin: historical review. Acta Universitatis Carolinae, Geologica 47(1-4), 53-61.

FATKA, O., Kordule, V. \& SzABAD, M. 2004. Stratigraphic distribution of Cambrian fossils in the Príbram-Jince Basin
(Barrandian area, Czech Republic). Senckenbergiana lethaea 84(1/2), 369-384.

FATKA, O. \& SZABAD, M. in press. Biostratigraphy of Cambrian in the Př́bram-Jince Basin (Barrandian area, Czech Republic). Bulletin of Geosciences.

FATKA, O., SZABAD, M. \& VOKÁČ, V. 2007. Middle Cambrian associations of miomerid trilobites from Barrandian area (Czech Republic). In ZlinsKÁ, A. (ed.) 8. paleontologická konference. Zborník abstraktov. Štátny geologický ústav Dionýza Štúra Bratislava, 32-34.

FORTEY, R.A. \& OWENS, R.M. 1999. Feeding habits in trilobites. Palaeontology 42(3), 429-465.

DOI 10.1111/1475-4983.00080

GRÖNWALL, K.A. 1902. Bornholms Paradoxideslag og deres Fauna. Danmarks geologiske Undersøgelse 2, 1-230.

HAVLÍČEK, V., VANĚK, J. \& FATKA, O. 1993. Floating algae of the genus Krejciella as probable hosts of epiplanktic organisms (Dobrotiv Series, Ordovician: Prague Basin). Journal of the Czech Geological Society 38(1-2), 79-88.

JAEKEL, O. 1909. Über die Agnostiden. Zeitschrift der Deutsche geologische Gesellschaft 61, 380-401.

JAGO, J.B. 1973. Cambrian agnostoid communities in Tasmania. Lethaia 6, 405-421.

DOI 10.1111/j.1502-3931.1973.tb01206.x

JAGO, J.B. 1974. Evidence for scavengers from Middle Cambrian sediments. Neues Jahrbuch für Geologie und Paläontologie, Monatshefte, 13-17.

LIN, J.-P. \& YUAN, J-L. 2008. Reassessment of the mode of life of Pagetia Walcott, 1916 (Trilobita: Eodiscidae) based on a cluster of intact exuviae from the Kaili Formation (Cambrian) of Guizhou, China. Lethaia.

LinNARSSON, J.G.O. 1869. Om Vestergötlands Cambriska och Siluriska aflagringar. Kongliga Svenska Vetenskapsakademiens Handlingar 8, 1-89.

LOCHMAN-BALK, C. 1940. Fauna of the basal Bonneterre Dolomite (Upper Cambrian) of southeastern Missouri. Journal of Paleontology 14(1), 1-53.

LOCHMAN-BALK, C. \& WILSON, J. 1958. Cambrian biostratigraphy in North America. Journal of Paleontology 32(2), 312-350.

MÜLlER, K.J. \& WALOSSEK, D. 1987. Morphology, ontogeny, and life habit of Agnostus pissiformis from the Upper Cambrian of Sweden. Fossils and Strata 19, 1-124.

NIELSEN, A. 1997. A review of Ordovician agnostik genera (Trilobita). Transactions of Royal Society of Edinburgh, Earth Sciences 87, 463-501.

OWEN, A.W. 1985. Trilobite Abnormalities. Transactions Royal Society Edinburgh, Earth Sciences 76, 255-272.

ÖPIK, A.A. 1961. The geology and palaeontology of the headwaters of the Burke River, Queensland. Bureau of Mineral Resources, Geology and Geophysics, Bulletin 53, 1-249.

ÖPIK, A.A. 1967. The Mindyallan fauna of North-Western Queensland. Bureau of Mineral Resources, Geology and Geophysics, Bulletin 74, 1-404.

ÖPIK, A.A. 1979. Middle Cambrian agnostids: systematics and biostratigraphy. Bureau of Mineral Resources, Geology and Geophysics, Bulletin 172, 1-188. 
PEK, I. 1977. Agnostid trilobites of the Central Bohemian Ordovician. Sborník geologických věd, Paleontologie 19, 7-44.

PŘIBYL, A. \& VANĚK, J. 1976. Palaeoecology of Berounian trilobites from the Barrandian area. Rozpravy České akademie věd, $\breve{R} a d a$ matematicko-př́rodních věd 86(5), 3-40.

RAYMOND, P.E. 1925. Some trilobites of the lower Middle Ordovician of eastern North America. Harward University Museum of Comparative Zoology Bulletin 67(1), 1-180.

RoBISON, R.A. 1972. Mode of life of agnostid trilobites. $24^{\text {th }}$ International Geological Congress, Montreal, Section 7, 33-40.

RoBISON, R.A. 1975. Specie diversity among agnostoid trilobites. Fossils and Strata 4, 219-226.

RoBISON, R.A. 1995. Revision of the Middle Cambrian trilobite Agnostus acadicus Hartt. Journal of Paleontology 69(2), 302-307.

SLAVÍČKOVÁ, J. \& KRAFT, P. 2001. Remarks to the palaeoecology of agnostik trilobites. Journal of the Czech Geological Society 46(3-4), 215-218.

ŠNAJDR, M. 1957. O nových trilobitech z českého středního kambria (On new trilobites of the Cambrian of Bohemia). Věstník Ústředního ústavu geologického 32, 235-244. [in Czech with English summary]

ŠNAJDR, M. 1958. Trilobiti českého středního kambria (The trilobites of the Middle Cambrian of Bohemia). Rozpravy Ústředního ústavu geologického 24, 1-280. [in Czech with English summary]
ŠNAJDR, M. 1978. Anomalous carapaces of Bohemian paradoxidid trilobites. Sborník geologických věd, Paleontologie 20, 1-31.

TULlBeRG, S.A. 1880. Om Agnostus-arterna i de kambriska aflagringarne vid Andrarum. Sveriges Geologiska Undersökning C42, 1-37.

TURVEY, S.T. \& ZHOU, Z. 2004. Arenig trilobite associations from the Jiangnan Transitional Belt of Northern Hunan, China. Journal of Asian Earth Sciences 23, 47-61. DOI 10.1016/S1367-9120(03)00094-4

VERMEIJ, G.J. 1987. Evolution and escalation - an ecological history of life. 527 pp. Princeton University Press, Princeton, New Jersey.

WALCOTT, C.D. 1912. Cambrian geology and Paleontology II: Middle Cambrian Brachnchiopoda, Malacostraca, trilobita and Merostomata. Smithsonian Miscellaneous Collections 57, 145-228.

WHITE, C.A. 1874. Preliminary report upon invertebrate fossils collected by the expeditions of 1871, 1872, and 1873: Geographical and geological exploration and surveys west of the $100^{\text {th }}$ Meridian. 27 pp. Government Printing Office, Washington, D.C.

WhitTington, H.B. 1997. Abnormalities of the exoskeleton. In KAESLER, R.L. (ed.) Treatise on Invertebrate Paleontology, Part O, Arthropoda 1, Trilobita (Revised). The Geological Society of America \& The University of Kansas, Boulder, Colorado \& Lawrence, Kansas. 